\title{
Osteoporosis in Chronic Hepatitis C
}

\author{
Abeer H. Abdelkader ${ }^{1}$, Ibraheem M. Hegazy ${ }^{1}$, Elased G.Elbadrawy ${ }^{1}$, \\ Ayman F. Zeid ${ }^{2}$, Jihan A. Shawky ${ }^{1}$, Soha A. El-Hawary ${ }^{1}$, Amal A. Jouda, \\ Mohamed H. Emara ${ }^{1}$ \\ ${ }^{1}$ Department of Tropical Medicine, Faculty of Medicine, Zagazig University, Egypt \\ ${ }^{2}$ Radiology Department, Faculty of Medicine, Zagazig University, Egypt \\ See editorial pages
}

Corresponding Author Abeer H. Abdelkader

Mobile:
+201121310542
Email:
ab_alashry@yahoo.co
$m$

Key words: Hepatitis C Virus, Bone Mineral Density, Osteoporosis, Cirrhosis
Background and study aim: Hepatitis C virus infection is a multisystemic disease with many extrahepatic manifestations. Affection of bone matrix density is a common complication of chronic hepatitis and cirrhosis. The pathogenesis of osteoporosis in chronic liver disease is still unknown and is expected to be multifactorial. The aim of this work is to assess the frequency of osteoporosis/osteopenia in patients with chronic hepatitis $\mathrm{C}$ virus infection with or without cirrhosis.

Patients and Methods: This study was carried out on 30 patients with chronic $\mathrm{HCV}$ infection without cirrhosis (Group II), 30 patients with chronic HCV infection with compensated cirrhosis (Group III) and 20 age and gender matched healthy controls (Group I). All subjects of the study performed liver function tests, viral markers, liver biopsy,

\section{INTRODUCTION}

Chronic hepatitis $\mathrm{C}(\mathrm{HCV})$ is systemic disease rather than hepatotropic and affects more than 170 million people worldwide [1]. It is associated with multisystemic manifestations. Liver disease is the most common affectation, and leads to liver cirrhosis and hepatocellular carcinoma [2]. Osteoporosis is a condition that is characterized by low bone mass and microarchitectural deterioration of bone tissue, leading to enhanced bone fragility and a consequent increase in fracture risk [3].

Osteoporosis and osteopenia are well known complications of chronic hepatitis as well as cirrhosis. Its prevalence varies considerably. It ranges from 12 to $55 \%$ according to patient selection, diagnostic criteria, underlying liver hormonal assay and Bone Mineral density measurement (BMD) by Dual energy Xray absorptiometry (DEXA).

Results: In patients with chronic hepatitis $\mathrm{C}$ (group II) the frequency of osteopenia was $11(36.7 \%)$, osteoporosis $2(6.7 \%)$, total patients with low BMD was 13 (43.3\%). In cirrhotic patients (group III), the frequency of osteopenia was 13 (43.3\%), osteoporosis was $3(10.0 \%)$, and total patients with low BMD was $16(53.3 \%)$ vs $1(5.0 \%)$ in the control group (group I). there was also no significant difference between patients with low BMD and patients with normal $\mathrm{BMD}$ as regards age, gender, common risk factors, liver function tests or hormonal levels.

Conclusion: Reduced BMD is common chronic HCV-infected patients with and without cirrhosis. HCV infection is a risk factor of osteoporosis.

disease and its severity [4,5]. Osteoporosis and osteopenia are common in chronic viral hepatitis as $\mathrm{HCV}$ and HBV [6]. Compensated as well as decompensated cirrhosis, whatever its cause, affects bone mineral density leading to osteopenia and osteoporosis [7]. Prevalence of osteoporosis in cirrhotic patients is related to the severity of liver disease expressed by the Child-Pugh score [8].

Osteopenia and osteoporosis are common in chronic HCV patients. In most studies suggesting that HCV by itself provokes osteopenia [9-12]. Some of this research involved noncirrhotic patients [12-14], others, individuals affected by liver cirrhosis $[9,11]$, or both cirrhotics and noncirrhotics [15,16], and some were restricted to patients awaiting organ transplantation $[17,18]$. 
The pathogenesis of osteoporosis in chronic liver disease is still unknown and it is likely that multiple factors are operating simultaneously [19]. The development of osteoporosis may be related to both increase bone resorption and/ or decrease bone formation [20]. Inhibition of osteoblast (bone forming cell) may be mediated by retained substances of cholestasis as unconjugated bilirubin, retained bile acids, toxic effect of alcohol, and excessive tissue iron deposition [21].

Various potential inciting factors that either directly or indirectly alter bone mass are insulinlike growth factor 1 (IGF-1) deficiency, hyperbilirubinemia, hypogonadism, subnormal 25hydroxyvitamin $\mathrm{D}$ levels, vitamin $\mathrm{D}$ receptor genotypes, vitamin $\mathrm{K}$, osteoprotegerin (OPG) and receptor activator of nuclear factor interactions and concurrent use of drugs like cholestyramine, diuretics, glucocorticoids and immunosuppressive agents [22], Lifestyle factors (smoking, alcoholism, immobility), malnutrition and low body mass index $[23,24]$. Increase osteoclast activity is cytokine mediated mechanism of bone loss. The pro-inflammatory cytokines interleukin-1 (IL-1) and tumor necrosis factor (TNF) increase osteoclast activity and are increased in hepatic inflammation and fibrosis. TNF increased in viral hepatitis and alcoholic liver disease as well as in patients with cirrhosis [25].

Osteoporosis is a risk factor for development of fracture, which may be a source of morbidity in patients already debilitated by chronic liver disease. Prevention of morbidity of hepatic osteodystrophy is to identify those patients who are predisposed to development of osteopenia and osteoporosis [26].

The aims of this study were to assess the frequency of osteoporosis in chronic hepatitis and post $\mathrm{HCV}$ cirrhosis in comparison with a group of age- and sex-matched healthy controls and to identify the main risk factors for its development.

\section{PATIENTSAND METHODS}

This study was conducted in the Department of Tropical Medicine, Zagazig University Hospitals, Egypt during the period from January 2012 to December 2013 and included 80 subjects. The subjects were divided into three groups: Group I: 20 apparently healthy individuals, Group II: 30 patients with chronic viral hepatitis $\mathrm{C}$ without cirrhosis, Group III: 30 patients with post hepatitis $\mathrm{C}$ compensated cirrhosis. The evidence of $\mathrm{HCV}$ infection was detected by anti-HCV antibody and HCV RNA.

\section{Exclusion criteria:}

1- Patients with liver disease due to multiple etiologies or with other liver conditions (HBV, primary biliary cirrhosis, autoimmune or metabolic cause like Diabetes Miletus, hemochromatosis, Willson`s disease).

2- Cholestatic liver disease.

3- Decompensated cirrhosis.

4- Postmenopausal women.

All patients and control groups were subjected to:

1- Complete history taking with history of previous bone fractures.

2- History of drug therapy as steroids.

3- History of smoking and alcohol.

4- Thorough physical examination with special emphasizes on the manifestations of chronic liver disease.

5- Laboratory investigations including:

- Complete blood picture.

- Liver functions tests: liver enzymes, serum total proteins, albumin, serum bilirubin, alkaline phosphates,

- Child- Pugh score

- Abdominal ultrasonography.

- HCV antibodies by ELISA.

- HCV RNA by quantatitive PCR.

- Serum calcium and phosphorus.

- Hormonal assay: Hormonal immunoassasy: These included Parathyroid hormone level, Gonadal hormones levels (Testosterone and estrogen levels), Thyroid hormone (T3,T4, TSH).

- Liver histopathology for diagnosis of chronic hepatitis C and cirrhosis: Pathological examination performed at liver histopathology laboratory at Pathology Department, Faculty of Medicine, Zagazig University. Hepatitis grading and staging were evaluated according to the METAVIR scoring system which consists of two separate score, one for necroinflammation grade (activity score A0-A3) is assessed by an algorithm of both piecemeal necrosis and lobular necrosis and another for the stage of fibrosis (F0-F4) [27].

- Bone Mineral density measurement (BMD) by Dual energy X-ray absorptiometry (DEXA) (Norland Excell X-ray bone densitometer From Norland Medical system, Inc. USA). Done on femoral neck (FN) and the lumbar spine (L2-L4) region, BMD was expressed as grams per square centimeter. T-score is the number of standard deviation of BMD 
value above or below a young reference value for individual of same ethnic background and gender.

\section{WHO classification of osteoporosis:}

- Normal BMD is represented by a T score of more than -1 (low risk of fracture).

- Osteopenia (low bone mass) is represented by a $\mathrm{T}$ score between -1and -2.5 (medium risk of fracture).

- Osteoporosis is presented by a $\mathrm{T}$ score less than -2.5 and a previous history of a fragility fracture (high spontaneous fracture probability) [28].

\section{Statistical analysis:}

Data were expressed as mean \pm SD for quantitative data and number and percentage for qualitative data and comparison was done by paired $t$ test and ANOVA for the former and corrected X2 for the latter.

\section{RESULTS}

The patients of the three studied groups had no significant differences as regards age and gender distribution as shown in Table 1. Males and females are almost equally represented in each group. The frequency of smoking and mean body mass index of each group were represented in Table 2 as common risk factors for osteoporosis with no significant differences found among the three studied groups.

The frequency of osteopenia/osteoporosis in the three studied groups is represented in table (3).
The comparison showed that the frequency of osteopenia/osteoporosis is highly significantly higher in group II and significantly higher in group III when compared to the control group I. The results of the hormonal assay for parathyroid hormone, sex hormones and thyroid hormones as well as thyroid stimulating hormone were compared among the three studied groups in table (4). It shows that the parathyroid hormone level was significantly higher in the compensated cirrhosis patients group (group II) than in the two other groups, also serum testosterone level was significantly lower in the compensated cirrhosis patients group (group II) than the other two groups.

In tables 5 and 6 the two patients groups were divided according to the presence or absence of bone disease into two groups. As presented in table 5, the patients without bone disease were compared to those with bone disease according to demographic data as well as common risk factors for osteoporosis/osteopenia and showed no significant difference between the two groups as regards any of these items. In table 6, there's comparison between the two groups as regards platelet count, total and direct bilirubin levels, total protein and albumen levels, prothrombin time, liver enzymes, serum calcium and phosphorus as well as parathormone and testosterone levels, showing no significant difference as regards any of these laboratory parameters.

Table (1): Demographic data of the studied groups

\begin{tabular}{|c|c|c|c|c|c|}
\hline 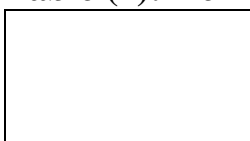 & $\begin{array}{c}\text { Group I } \\
\mathbf{N}=20 \\
\text { (No. \&\%) }\end{array}$ & $\begin{array}{c}\text { Group II } \\
\mathbf{N}=\mathbf{3 0} \\
\text { (No. \&\%) }\end{array}$ & $\begin{array}{c}\text { Group III } \\
\mathbf{N}=\mathbf{3 0} \\
\text { (No. \&\%) }\end{array}$ & $\mathbf{F}$ & P-value \\
\hline $\begin{array}{r}\text { Age (years) } \\
\text { X } \pm \text { SD } \\
\text { Range }\end{array}$ & $\begin{array}{c}38.6 \pm 9.6 \\
22-56\end{array}$ & $\begin{array}{c}39.6 \pm 8.4 \\
22-55\end{array}$ & $\begin{array}{c}39 \pm 9.6 \\
25-53\end{array}$ & 0.09 & $0.914 *$ \\
\hline & No (\%) & No (\%) & No (\%) & $\chi^{2}$ & \\
\hline Female & $3(15.0)$ & $4(13.3)$ & $4(13.3)$ & \multirow{2}{*}{0.04} & \multirow{2}{*}{$0.983^{*}$} \\
\hline Male & $17(85.0)$ & $26(86.7)$ & $26(86.7)$ & & \\
\hline
\end{tabular}

* Non-significant

Table (2): Frequency of the common risk factors of osteoporosis in different studied groups

\begin{tabular}{|l|c|c|c|c|c|}
\hline & $\begin{array}{c}\text { Group I } \\
\mathbf{N = 2 0} \\
(\mathbf{N o . ~ \& \% ) ~}\end{array}$ & $\begin{array}{c}\text { Group II } \\
\mathbf{N = 3 0} \\
(\mathbf{N o . ~ \& \% )}\end{array}$ & $\begin{array}{c}\text { Group III } \\
\mathbf{N = 3 0} \\
(\mathbf{N o . ~ \& \% )}\end{array}$ & $\chi^{\mathbf{2}}$ & P. value \\
\hline Smoking & $1(5.0)$ & $4(13.3)$ & $0(0.0)$ & 4.62 & $0.099^{*}$ \\
\hline \multirow{2}{*}{ Body mass index (BMI) } & $26 \pm 6.4$ & $26.04 \pm 3.2$ & $27.2 \pm 3$ & 0.788 & $0.458^{*}$ \\
\cline { 2 - 7 }
\end{tabular}


Table (3): Frequency of osteopenia/osteoporosis among studied groups

\begin{tabular}{|c|c|c|c|c|c|c|}
\hline \multirow[t]{2}{*}{ 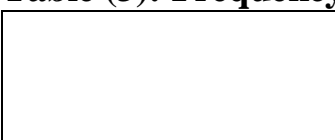 } & \multicolumn{2}{|c|}{$\begin{array}{c}\text { Group I } \\
\mathbf{N}=20\end{array}$} & \multicolumn{2}{|c|}{$\begin{array}{c}\text { Group II } \\
\mathbf{N}=\mathbf{3 0}\end{array}$} & \multicolumn{2}{|c|}{$\begin{array}{c}\text { Group III } \\
\mathbf{N}=\mathbf{3 0}\end{array}$} \\
\hline & $\mathbf{N}$ & $\%$ & $\mathbf{N}$ & $\%$ & $\mathbf{N}$ & $\%$ \\
\hline Normal & 19 & 95.0 & 17 & 56.7 & 14 & 46.7 \\
\hline Osteopenia & 1 & 5.0 & 11 & 36.7 & 13 & 43.3 \\
\hline Osteoprosis & 0 & 0.0 & 2 & 6.7 & 3 & 10.0 \\
\hline Total bone disease & 1 & 5.0 & 13 & 43.3 & 16 & 53.3 \\
\hline \multicolumn{3}{|c|}{$\begin{array}{l}\mathbf{X}^{2} \\
\mathbf{P}\end{array}$} & \multicolumn{2}{|c|}{$\begin{array}{c}8.75 \\
<0.01 * *\end{array}$} & \multicolumn{2}{|c|}{$\begin{array}{c}12.49 \\
<0.001^{* * *}\end{array}$} \\
\hline
\end{tabular}

Table (4): Hormonal assay of different studied groups using analysis of variance by (ANOVA test).

\begin{tabular}{|c|c|c|c|c|c|}
\hline Variables & $\begin{array}{c}\text { Group I } \\
\mathrm{N}=\mathbf{2 0} \\
X \pm S D \\
\end{array}$ & $\begin{array}{c}\text { Group II } \\
\mathrm{N}=\mathbf{3 0} \\
X \pm S D\end{array}$ & $\begin{array}{c}\text { Group III } \\
\mathbf{N}=\mathbf{3 0} \\
X \pm S D\end{array}$ & $\mathbf{F}$ & $P$ value \\
\hline \multicolumn{6}{|l|}{\begin{tabular}{|l|l} 
Parathyroid hormones levels \\
\end{tabular}} \\
\hline PTH (7 - 53) pg/ml & $41.6 \pm 6.9$ & $40 \pm 10.2$ & $47.6 \pm 13.1$ & 4.078 & $0.021 * *$ \\
\hline \multicolumn{6}{|l|}{ Gonadal hormones levels } \\
\hline $\begin{array}{l}\text { Total testosterone }(\mathrm{ng} / \mathrm{ml}) \quad(\text { men } \\
\left.2.8 \_8 \text { \& women } 0.06-0.82\right)\end{array}$ & $6.4 \pm 2.8$ & $5.6 \pm 2.4$ & $4.4 \pm 2.1$ & 4.755 & $0.011^{* *}$ \\
\hline Estradiol $(\mathrm{pg} / \mathrm{ml})$ & $49.8 \pm 51.4$ & $53.3 \pm 28.3$ & $52 \pm 40.4$ & 0.047 & $0.954 *$ \\
\hline \multicolumn{6}{|l|}{ Thyroid hormones } \\
\hline Total T3 $(1.3-3.1) \mathrm{nmol} / \mathrm{l}$ & $2.2 \pm 0.6$ & $2.2 \pm 0.4$ & $2.3 \pm 0.4$ & 0.175 & $0.84 *$ \\
\hline Total T4 ( 66-181) nmol/1 & $108.8 \pm 40$ & $125.2 \pm 30$ & $127.1 \pm 20$ & 2.58 & $0.081 *$ \\
\hline $\mathrm{TSH}(0.3-4.2) \mathrm{uIU} / \mathrm{ml}$ & $2.4 \pm 0.97$ & $2.1 \pm 1$ & $1.9 \pm 1$ & 1.426 & $0.247 *$ \\
\hline
\end{tabular}

Table (5): Demographic and clinical factors associated with bone disease in patients of HCV cirrhosis (group III) and chronic viral hepatitis C (group II)

\begin{tabular}{|c|c|c|c|c|c|c|}
\hline & \multicolumn{2}{|c|}{$\begin{array}{c}\text { Without bone disease } \\
\qquad \mathrm{N}=31\end{array}$} & \multicolumn{2}{|c|}{$\begin{array}{c}\text { With bone disease } \\
\mathrm{N}=29\end{array}$} & $\begin{array}{c}\text { Test of } \\
\text { significance }\end{array}$ & $\mathbf{P}$ \\
\hline $\begin{array}{c}\text { Age (years) } \\
\overline{\mathbf{X}} \pm \text { SD } \\
\text { Range }\end{array}$ & \multicolumn{2}{|c|}{$\begin{array}{c}38.5 \pm 7.8 \\
22-52\end{array}$} & \multicolumn{2}{|c|}{$\begin{array}{c}42.0 \pm 701 \\
28-55\end{array}$} & 1.81 & $0.07 *$ \\
\hline $\begin{array}{c}\text { Gender } \\
\text { Male } \\
\text { Female }\end{array}$ & $\begin{array}{l}\text { No } \\
26 \\
5\end{array}$ & $\begin{array}{c}\% \\
83.9 \\
16.1\end{array}$ & $\begin{array}{l}\text { No } \\
26 \\
3\end{array}$ & $\begin{array}{r}\% \\
89.7 \\
10.3\end{array}$ & $\begin{array}{c}\mathrm{X} 2 \\
0.08\end{array}$ & $0.78 *$ \\
\hline $\begin{array}{c}\text { Smoking } \\
\text { Negative } \\
\text { Positive }\end{array}$ & $\begin{array}{l}\text { No } \\
29 \\
2\end{array}$ & $\begin{array}{r}\% \\
93.5 \\
6.5\end{array}$ & $\begin{array}{l}\text { No } \\
27 \\
2\end{array}$ & $\begin{array}{c}\% \\
93.1 \\
6.9\end{array}$ & 0.2 & $0.65^{*}$ \\
\hline $\begin{array}{r}\text { BMI } \\
\text { X } \pm \text { SD } \\
\text { Range }\end{array}$ & \multicolumn{2}{|c|}{$\begin{array}{c}26.6 \pm 3.2 \\
22-33\end{array}$} & \multicolumn{2}{|c|}{$\begin{array}{c}26.3 \pm 301 \\
21-33\end{array}$} & $\begin{array}{c}\mathrm{T} \\
0.32\end{array}$ & $0.7^{*}$ \\
\hline
\end{tabular}


Table (6): Some laboratory parameter and its relation to bone disease

\begin{tabular}{|c|c|c|c|c|}
\hline & \begin{tabular}{|c|}
$\begin{array}{c}\text { Without bone disease } \\
\mathrm{N}=31\end{array}$ \\
\end{tabular} & $\begin{array}{c}\text { With bone disease } \\
\mathrm{N}=29\end{array}$ & $\mathbf{t}$ & $\mathbf{P}$ \\
\hline $\begin{array}{c}\text { Platelets } \times 10^{3} / \mathrm{mm} \\
\overline{\mathrm{X}} \pm \mathrm{SD} \\
\text { Range }\end{array}$ & $\begin{array}{l}154 \pm 56 \\
77-260\end{array}$ & $\begin{array}{c}135 \pm .55 .1 \\
75-247\end{array}$ & 103 & $0.19 *$ \\
\hline $\begin{array}{c}\text { Total bilirubin } / \mathrm{mg} \% \\
\overline{\mathrm{X}} \pm \mathrm{SD} \\
\text { Range }\end{array}$ & $\begin{array}{c}1.69 \pm 0.5 \\
0.9-2.9\end{array}$ & $\begin{array}{c}1.73 \pm 0.6 \\
0.7-3.1\end{array}$ & 0.28 & $0.77 *$ \\
\hline $\begin{array}{r}\text { Direct } / \mathrm{mg} \% \\
\overline{\mathrm{X}} \pm \mathrm{SD} \\
\text { Range }\end{array}$ & $\begin{array}{l}0.36 \pm 0.35 \\
0.2-1.5\end{array}$ & $\begin{array}{l}0.640 .3 \\
0.1-1.6\end{array}$ & 0.04 & $0.96 *$ \\
\hline $\begin{array}{c}\text { Protein } / \mathrm{gm} \% \\
\overline{\mathrm{X}} \pm \mathrm{SD} \\
\text { Range }\end{array}$ & $\begin{array}{l}7.8 \pm 0.5 \\
7-9\end{array}$ & $\begin{array}{l}7.9 \pm 0.5 \\
7-9.2\end{array}$ & 0.85 & $0.39 *$ \\
\hline $\begin{array}{r}\text { Albumin/gm\% } \\
\overline{\mathrm{X}} \pm \mathrm{SD} \\
\text { Range }\end{array}$ & $\begin{array}{l}4.3 \pm 0.3 \\
3.5-4.8\end{array}$ & $\begin{array}{l}4.2 \pm 0.3 \\
3.4-4.8\end{array}$ & 1.46 & $0.14 *$ \\
\hline \begin{tabular}{|c} 
ALT x IU \\
$\bar{X} \pm$ SD \\
Range \\
\end{tabular} & $\begin{array}{l}46.8 \pm 10.7 \\
22-70\end{array}$ & $\begin{array}{l}46.6 \pm 16.7 \\
20-93\end{array}$ & 0.06 & $0.95^{*}$ \\
\hline $\begin{array}{r}\text { AST x IU } \\
\bar{X} \pm \text { SD } \\
\text { Range } \\
\end{array}$ & $\begin{array}{c}47.6 \pm 13.6 \\
20-75 \\
\end{array}$ & $\begin{array}{l}47.7 \pm 13.1 \\
20-77\end{array}$ & 0.01 & $0.98^{*}$ \\
\hline $\begin{array}{c}\text { ALK x IU } \\
\bar{X} \pm \text { SD } \\
\text { Range }\end{array}$ & $\begin{array}{c}159.5 \pm 34 \\
110-222\end{array}$ & $\begin{array}{l}169.1 \pm 36.9 \\
120-240\end{array}$ & 1.04 & $0.29 *$ \\
\hline $\begin{array}{r}\text { PT/ Seconds } \\
\bar{X} \pm \text { SD } \\
\text { Range }\end{array}$ & $\begin{array}{l}12.7 \pm 1.3 \\
11-16\end{array}$ & $\begin{array}{c}13.3 \pm 1.8 \\
11-17\end{array}$ & 1.6 & $0.11^{*}$ \\
\hline $\begin{array}{r}\mathrm{PTH} / p g / m l \\
\overline{\mathrm{X}} \pm \mathrm{SD} \\
\text { Range } \\
\end{array}$ & $\begin{array}{l}45.1 \pm 10 \\
22.6-73\end{array}$ & $\begin{array}{c}42.3 \pm 14 \\
21-72\end{array}$ & 0.87 & $0.38^{*}$ \\
\hline $\begin{array}{c}\text { Calcium } \\
\overline{\mathrm{X}} \pm \mathrm{SD} \\
\text { Range } \\
\end{array}$ & $\begin{array}{c}9.1 \pm 0.5 \\
8.2-10\end{array}$ & $\begin{array}{c}8.2 \pm 0.7 \\
7.1-10\end{array}$ & 1.06 & $0.29 *$ \\
\hline $\begin{array}{c}\text { Phosphate } \\
\overline{\mathrm{X}} \pm \mathrm{SD} \\
\text { Range }\end{array}$ & $\begin{array}{l}3.9 \pm 0.4 \\
2.7-4.5\end{array}$ & $\begin{array}{l}3.8 \pm 0.4 \\
2.8-4.5\end{array}$ & 0.83 & $0.4^{*}$ \\
\hline $\begin{array}{c}\text { Total testosterone } \mathrm{x} \mathrm{ng} / \mathrm{ml} \\
\overline{\mathrm{X}} \pm \mathrm{SD} \\
\text { Range. }\end{array}$ & $\begin{array}{l}4.5 \pm 3.1 \\
0.05-9.5\end{array}$ & $\begin{array}{l}\mathbf{5 . 7} \pm 2.6 \\
0.2-10.1\end{array}$ & 1.237 & $0.221 *$ \\
\hline
\end{tabular}

\section{DISCUSSION}

The aim of this study was to test if $\mathrm{HCV}$ infection alone can be a risk factor for bone disease before causing severe liver damage that intervenes with the patient's nutritional status and bone metabolism. Studying HCV as risk factor for bone disease depended on the fact that $\mathrm{HCV}$ is actually a systemic illness that has so many extrahepatic manifestations.

In our study, there were no significant differences between the three studied groups as regards age and gender distribution as well as common risk factors of low BMD. This neutralization of risk factors and exclusion of decompensated cirrhosis, 
cholestasis and postmenopausal females will help focus on $\mathrm{HCV}$ alone and avoid a confounding factor.

In patients with chronic hepatitis C (group II) the frequency of osteopenia was $11(36.7 \%)$, osteoporosis $2(6.7 \%)$, total patients with low BMD was 13 (43.3\%). In cirrhotic patients (group III), the frequency of osteopenia was $13(43.3 \%)$, osteoporosis was $3(10.0 \%)$, and total patients with low BMD was $16(53.3 \%)$ vs $1(5.0 \%)$ in the control group (group I). The previous studies showed wide variability in their results. Tsuneoka et al. [29] found osteoporosis in $20 \%$ of patients with chronic hepatitis and in $40 \%$ of patients with cirrhosis. Duarte et al. [15] found low BMD values in about $20-25 \%$ of $\mathrm{HCV}$ affected patients. Sokhi et al. [30] found that osteopenia in the cirrhotic patients awaiting liver transplantation was $34.6 \%$ and that of osteoporosis was $11.5 \%$. Schiefke et al. [12] found that osteoporosis affected $26 \%$ in viral hepatitis B and C. Bunchorntavakul et al. [31] found that osteoporosis and osteopenia were $3.5 \%$ and $22.8 \%$, respectively in chronic hepatitis $\mathrm{C}$ in Thai patients. Turkeli et al. [32] estimated the prevalence of osteopenia and osteoporosis in cirrhotic patients to be $45 \%$ and $42.5 \%$, respectively. Javed et al. [33] found osteoporosis in $26 \%$ and osteopenia in $42 \%$ of patients with cirrhosis due to viral hepatitis. George et al. [34] found decreased BMD in 68\% in cirrhosis patients. Goral et al. [35] found osteoporosis in $37 \%$ of patients with cirrhosis. Another study by Goubraim et al. [36] found a high prevalence of BMD abnormalities in cirrhotic patients (post viral $\mathrm{B}, \mathrm{C}$ ) with total rate of $80.4 \%$, osteoporosis was found in $28.2 \%$ of cases and osteopenia in $52.2 \%$ of cases. Some Egyptian studies have also found high rates of bone loss in patients with cirrhosis: $87.8 \%$ in Salama et al. [37] and $86.6 \%$ in Ahmed et al. [38]. These variable percentages of bone disease in chronic $\mathrm{HCV}$ in comparison to this study may be related to age, gender, stage of liver disease as well as nutritional state and most studies which reported high percentage were decompensated cirrhosis.

In the present study testosterone was mild decreased in cirrhotic group in comparison to chronic hepatitis $\mathrm{C}$ and control group but all within normal range with no effect on bone disease (no significant difference between patients with low BMD and patients with normal BMD. This was in agreement with Gallego-Rojo et al. [39], Wariaghli et al. [19] and Pelazas-
González et al. [40] who found that Patients with HCV infection had significantly lower testosterone levels than controls, but no effect on bone disease. This finding in our study disagrees with George et al. [34] who found high incidence of hypogonadism in patients with cirrhosis with no relation to bone disease and Diamond et al. [41] who reported that the two major risk factors for the development of osteoporosis were cirrhosis itself and hypogonadism. The explanation of that debate may be that most patients in our study were middle-aged, wellnourished and had good general condition, good liver function and those who had cirrhosis were compensated. Hypogonadism in most studies was mostly related to the severity of liver disease, alcohol intake and nutritional state.

In this study, there was no significant difference between serum calcium, phosphorus, or parathyroid hormone $(\mathrm{PTH})$ with low BMD patients and patients with normal BMD. Although, PTH mild increase in cirrhotic group. This is in agreement with Karan et al. [42], Schiefke et al. [12] Goral et al. [35], Goubraim et al. [36] who found high PTH level in cirrhotic patients but with no difference between patients with normal BMD and those with osteoporosis or osteopenia. Our study also agrees with Duarte et al. [15], Bunchorntavakul et al. [31], George et al. [34] and El Karmouty et al. [43] who found serum calcium, phosphorus and PTH levels were insignificantly different in patients with normal BMD and patients with low BMD.

Our study disagrees with that of Bai et al. [44] who found that an increased level of PTH was an independent risk factor associated with low BMD. Also, Younes et al. [45] who recorded a significant increase in serum PTH level in patients with cirrhosis but serum PTH was inversely correlated with BMD. This could be explained by the fact that the role of calciumparathyroid hormone-vitamin D axis in hepatic osteodystrophy is controversial and still unclear $[46,47]$

There was no difference in age and gender between patients with low BMD and patients with normal BMD. This finding disagrees with Tsuneoka et al. [29] and Ormarsdottir et al. [48] who found that the advanced age of patients was an independent risk factor of osteoporosis in patients with chronic liver disease including chronic hepatitis and cirrhosis. Also Figueiredo et al. [49] who found that there was a significantly 
lower BMD in post-menopausal female patients compared to male and pre-menopausal patients. And Sokhi et al. [30], Mahmoudi et al. [50] who found that female gender is a predictive factor of the occurrence of metabolic bone disorders particularly osteoporosis in patients with cirrhosis. This conflict can be due to the fact that most patients in this study were males in middle age, small percentage were female in child bearing period.

Sambrook and Cooper [51] explained the role of age and gender in their study as follows, patients with liver cirrhosis older than 50 years had lower BMD and Peak adult bone mass is achieved early in life, with a gradual, progressive decline in BMD beginning at about age 40 to 45 years but more rapidly in women, for whom the decline accelerates after menopause [51].

There was no difference as regard smoking and body mass index (BMI) as common risk factors in diseased and control groups. Also no difference between patients with normal BMD and patients with low BMD. This is in agreement with Ormarsdottir et al. [48]; Salama et al. [37]; George et al. [34]; Goral et al. [35] who found that there were no significant differences as regard BMI, between the patients with normal and low BMD. This was in disagreement with Goubraim et al. [36] who found that patients with low BMD have a lower BMI compared with those with normal BMD. This could be explained by that BMI was in average range and smoker was small percentage $(13.3 \%$ in $\mathrm{HCV}, 5 \%$ in control group) in diseased and healthy control groups respectively.

In the present study there were no significant differences as regards liver biochemistry (ALT, AST, ALP, bilirubin, serum protein, serum albumin, prothrombin time) between patients with low BMD and patients with normal BMD. This is in agreement with Smith et al. [26] who found no correlation between serum bilirubin and reduced BMD in patients with end-stage liver disease [26].

Finding in this study that disagrees with Menon et al. [52], Karan et al. [42], Uretmen et al. [53] and Goral et al. [35] who found that there is a negative correlation between serum bilirubin level and BMD. This study also disagrees with El Karmouty et al. [43] who found significant negative correlation between serum bilirubin, prothrombin time and $\mathrm{BMD}$, also a highly significant positive correlation between BMD and serum albumin in patients with chronic liver disease. Our study also disagrees with Corazza et al. [9] and Figueiredo et al. [49] who found a highly significant positive correlation between BMD measurements and serum albumin levels. Also, Duarte et al. [15] who reported significant negative correlation between BMD measurements and prothrombin time. This could be explained by that BMD values were affected with the deterioration in liver functions and patients in this present study were with good liver function and the cirrhotic patients were compensated liver disease (child A).

\section{CONCLUSION}

Osteoporosis and its milder form osteopenia are an important extrahepatic manifestation of chronic HCV. Reduced BMD is common in chronic HCV-infected patients. HCV infection is a risk factor of osteoporosis.

Ethical approval:approved.

Funding:None.

\section{Conflict of interest:None.}

\section{REFERENCES}

1. Lavanchy D. Evolving epidemiology of hepatitis C virus. Clin Microbiol Infect 2011; 17(2):107-115.

2. Mueller S, Millonig G, Seitz HK. Alcoholic liver disease and hepatitis C: a frequently underestimated combination. World J Gastroenterol 2009; 15: 3462-71.

3. World Health Organization Study Group. Assessment of fracture risk and its application to screening for postmenopausal osteoporosis. World Health Organ Tech Rep Ser. 1994; 843:1-129.

4. Guichelaar M, Kendall R, Malinchoc M, Hay JE. Bone mineral density before and after OLT: longterm follow-up and predictive factors .Liver Transpl. Sep 2006; 12(9):1390-402.

5. Lin J, Hsieh T, Wu C, Chen P, Chueh T, Chang W, et al. Association between chronic hepatitis $\mathrm{C}$ virus infection and bone mineral density. Calcif Tissue Int. Dec 2012; 91(6):423-9.

6. Yurci A, Kalkan A, Ozbakir O, Karaman A, Torun E, Kula M, et al. Efficacy of different therapeutic regimens on hepatic osteodystrophy in chronic viral liver disease. Eur J Gastroenterol Hepatol. 2011; 23(12):1206-12.

7. Orsini L, Pinheiro M, Castro C, Silva A, Szejnfeld $\mathrm{V}$. Bone mineral density measurements, bone markers and serum vitamin D concentrations in men with chronic non-cirrhotic untreated hepatitis C. PLoS One. 2013; 8(11):e81652. 
8. López-Larramona G, Lucendo A, González-Castillo S, Tenias J. Hepatic osteodystrophy: An important matter for consideration in chronic liver disease. World J Hepatol. 2011; 3(12):300-7.

9. Corazza G, Trevisani F, Di Stefano M, De Notariis $\mathrm{S}$, Veneto G, Cecchetti L, et al. Early increase of bone resorption in patients with liver cirrhosis secondary to viral hepatitis. Dig Dis Sci 2000; 45: 1392-9.

10. Yousfi M, Douglas D, Harrison E, Mulligan D, Moss A, Vargas H, et al. End-stage liver disease secondary to hepatitis $\mathrm{C}$ infection and alcohol is a risk factor for osteoporosis. Hepatology 2001; 34: 231A.

11. Carey E, Balan V, Kremers W, Hay J. Osteopenia and osteoporosis in patients with end-stage liver disease caused by hepatitis $\mathrm{C}$ and alcoholic liver disease: not just a cholestatic problem. Liver Transplant 2003; 9: 1166-1173.

12. Schiefke I, Fach A, Wiedmann M, Aretin A, Schenker E, Borte G, et al. Reduced bone mineral density and altered bone turnover markers in patients with non cirrhotic chronic hepatitis B or C infection. World J Gastroenterol 2005; 11: 1843-1847.

13. Hofmann W, Kronenberger B, Bojunga J, Stamm B, Herrmann E, Bücker A et al, Prospective study of bone mineral density and metabolism in patients with chronic hepatitis $\mathrm{C}$ during pegylated interferon alpha and ribavirin therapy. J Viral Hepat 2008;15(11):790-6.

14. Nanda K, Ryan E, Murray B, Brady J, McKenna $\mathrm{M}$, Nolan N, et al. Effect of chronic hepatitis C virus infection on bone disease in postmenopausal women. Clin Gastroenterol Hepatol 2009; 7(8):894-9.

15. Duarte $M$, Farias $M$, Coelho $H$, Mendonca L,Stabnov L, do Carmo d Oliveira $M$, et al. Calcium-parathyroid hormone-vitamin D axis and metabolic bone disease in chronic viral liver disease. J Gastroenterol Hepatol 2001; 16(9): 1022-7.

16. Raslan H, Elhosary Y, Ezzat W, Rasheed E, Rasheed M. The potential role of insulin-like growth factor 1, insulin-like growth factor binding protein 3 and bone mineral density in patients with chronic hepatitis $\mathrm{C}$ virus in Cairo, Egypt. Trans R Soc Trop Med Hyg. 201; 104(6): 429-432.

17. Trautwein C, Possienke M, Schlitt H, Böker K, Horn R, Raab R, et al. Bone density and metabolism in patients with viral hepatitis and cholestatic liver diseases before and after liver transplantation. Am J Gastroenterol 2000; 95:2343-51.
18. Loria I, Albanese C, Giusto M, Galtieri P, Giannelli V, Lucidi C, et al. Bone disorders in patients with chronic liver disease awaiting liver transplantation. Transplant Proc. 2010; 42(4): 1191-3.

19. Wariaghli G, Allali F, El Maghraoui A, HajjajHassouni N. Osteoporosis in patients with primary biliary cirrhosis. Eur J Gastroenterol Hepatol. 2010; 22(12):1397-401.

20. Mualouf $\mathrm{N}$ and Sakhaee K. Treatment of Osteoporosis in Patients with Chronic Liver Disease and in Liver Transplant Recipients. Curr Treat Options Gastroenterol 2006; 9(6):456-63.

21. Guañabens N, Parés A. Osteoporosis in liver cirrhosis. Gastroenterol Hepatol. 2012; 35(6): 411-20.

22. Goel V, Kar P. Hepatic osteodystrophy. Trop Gastroenterol. 2010;31(2):82-6.

23. Hay J, Guichelaar M. Evaluation and management of osteoporosis in liver disease. Clin Liver Dis. 2005; 9: 747-766.

24. Gasser R. Cholestasis and metabolic bone diseasea clinical review. Wien Med Wochenschr 2008; 158: 553-557.

25. Luxon B. Bone disorders in chronic liver diseases. Curr Gastroenterol Rep. 2011 2011; 13(1):40-8.

26. Smith D, Shire N, Watts N, Schmitter T, Szabo $\mathrm{G}$, Zucker S, et al. Hyperbilirubinaemia is not a major contributing risk factor to altered bone mineral density in patients with chronic liver disease. J Clin Densitom 2006; 9(1):105-113.

27. Bedossa P, Poynard T. An algorithm for the grading of activity in chronic hepatitis C.The METAVIR Cooperative Study Group. Hepatology. 1996; 24(2):289-93

28. Blake G, Fogelman I. The role of DXA bone density scans in the diagnosis and treatment of osteoporosis. Postgrad Med J 2007;83 (982):50917.

29. Tsuneoka K, Tameda Y, Takase K, Nakano T. Osteodystrophy in patients with chronic hepatitis and liver cirrhosis. J Gastroenterol 1996; 31:66978 .

30. Sokhi R, Anantharaju A, Kondaveeti R, Creech $\mathrm{S}$, Islam K, Van Thiel D, et al. "Bone mineral density among cirrhotic patients awaiting liver transplantation," .Liver Transplantation. 2004; 10(5):648-653.

31. Bunchorntavakul C, Chotiyaputta W, Sriussadaporn $\mathrm{S}$, Tanwandee T. Bone Mineral Density in Thai Patients with Chronic Hepatitis $\mathrm{C}$ before and after Treatment with Pegylated Interferon/Ribavirin Combination.Thai J Gastroentrol. 2007;8:27377. 
32. Turkeli M , Dursun H, Albayrak F, Uyanik M, Uyanik A, Keleş M, et al. Effects of Cirrhosis on Bone Mineral Density and Bone Metabolism. The Eurasian Journal of Medicine 2008;40; 18-24.

33. Javed M, Saeed A, Khan I, Hameed K, Khattak A, Ahmad I, et al. frequency of osteoporosis in patients with cirrhosis due to hepatitis B and hepatitis C: a study of 100 cases. J Ayub Med Coll Abbottabad 2009; 21(3) 50-53.

34. George J, Ganesh H, Acharya S, Bandgar T, Shivane V, Karvat A, et al. Bone mineral density and disorders of mineral metabolism in chronic liver disease. World J Gastroenterol 2009; 15(28): 3516-22

35. Goral V, Simsek M, Mete N. Hepatic osteodystrophy and liver cirrhosis. World J Gastroenterol. 2010; 16(13):1639-43.

36. Goubraim R, Kabbaj N, Salihoun M, Chaoui Z, Nya M, Amrani N, et al. Metabolic Bone Disease in Viral Cirrhosis: A Prospective Study. ISRN Hepatology 2013, Article ID 276563, 6 pages.

37. Salama A, Lotfy A, El Aeizy H. Evaluation of hepatic osteodystrophy in patients with liver cirrhosis and correlation with severity of liver disease. Arab J Gastroenterol 2007; 8(1): 10-14.

38. Ahmed H, El-Shereef H, El-Gendi S, El-Sherif W, Bakheet M, Galal G, et al. Leptin, osteocalcin, and bone mineral density in post-hepatitic liver cirrhosis. Arab J Gastroenterol 2010; 11(3):130135.

39. Gallejo-Rojo F, Gonzalez-Calvin J, Munoz-Torres M, Mundi J, Fernandez-Perez R, RodrigoMoreno D, et al. Bone mineral density, serum insulin like growth factor I and bone turnover markers in viral cirrhosis. Hepatology 1998; 28(3): 695-699.

40. Pelazas-González R, González-Reimers E, Alemán-Valls M, Santolaria-Fernández F,LópezPrieto J, González-Díaz A, et al. Bone alterations in hepatitis C virus infected patients. Eur J Intern Med. 2013; 24(1):92-96.

41. Diamond T, Stiel D, Lunzer M, Wilkinson M, Roche J, Posen S. Osteoporosis and skeletal fractures in chronic liver disease. Gut 1990; 31(1): 82-87.

42. Karan M, Erten N, Tascioglu C, Karan A, Sindel D, Dilsen G, et al. Osteodystrophy in posthepatitic cirrhosis. Yonsei Medical Journal 2001; 42(5):547-552.
43. El Karmouty K, Keddeas M, El Sayed E. Osteodystrophy in Hepatitis $\mathrm{C}$ virus Related Cirrhosis. Nature and Science. 2010;8(12):158163.

44. Bai X, Liang T, Wu L, Li D, Geng L, Wang W, et al. Elevation of intact parathyroid hormone level is a risk factor for low bone mineral density in pretransplant patients with liver diseases. Transplantation Proceedings. 2007;39 (10): 3182-3185.

45. Younes K, Elbatae H, El-Shamy K, Ahmad Y, Assal H, Koriem K,et al. Hepatic Osteodystrophy in male patients with liver cirrhosis secondary to hepatitis c virus. Journal of Applied Sciences Research 2011; 7(9): 1356-1360.

46. Moriera R, Durta M, Farias M. Disturbance of calcium - PTH- Vitamin D axis in chronic liver disease. Arq Bras Endocrinal. Metabol 2004; 48:443-50.

47. Miroliaee A, Nasiri-Toosi M, Khalilzadeh O, Esteghamati A, Abdollahi A, Mazloumi M. Disturbances of parathyroid hormone-vitamin D axis in non-cholestatic chronic liver disease: a cross-sectional study. Hepatol Int. 2010; 4(3): 634-40.

48. Ormarsdottir S, Ljunggren O, Mallmin H, Brahm $\mathrm{H}$, Loof L. Low body mass index and use of corticosteroids, but not cholestasis, are risk factors for osteoporosis in patients with chronic liver disease. J Hepatol 1999;31(1):84-90.

49. Figueiredo FA, Brandão C, Perez Rde M, Barbosa $\mathrm{W}$, Kondo M. Low bone mineral density in noncholestatic liver cirrhosis: prevalence, severity and prediction.Arq Gastroenterol. 2003; 40(3) : 152-8.

50. Mahmoudi A, Sellier N, Reboul-Marty J, Chalès G,Lalatonne Y, Bourcier V, et al. Bone mineral density assessed by dual-energy $\mathrm{X}$-ray absorptiometry in patients with viral or alcoholic compensated cirrhosis. A prospective study. Clin Res Hepatol Gastroenterol. 2011; 35(11):731-7.

51. Sambrook P, Cooper C. Osteoporosis. Lancet. 2006 ; 367(9527):2010-2018.

52. Menon K, Angulo P, Weston S, Dickson E, Lindor $\mathrm{K}$, et al. Bone disease in primary biliary cirrhosis: independent indicators and rate of progression. J Hepatol. 2001;35(3): 316-323.

53. Uretmen S, Gol M, Cimrin D, Irmak E. Effects of chronic liver disease on bone mineral density and bone metabolism markers in post-menopausal women. Eur J Obestet Gynecol Reprod Biol. 2005; 123: 67-71. 
Peer reviewer: Nader Aly Elmalky, assistant professor of Hepatology and Gastroentrology, Faculty of Medicine, Mansoura university Egypt. Sahar Elnimr, assistant professor of Tropical Medicine and Hepatogastroenterology, Faculty of Medicine, Zagazig University, Egypt.Editor:Tarik Zaher: professor of Tropical Medicine and Hepatogastroenterology, Faculty of Medicine, Zagazig University, Egypt 